ЛЕГКА О. В., доктор юридичних наук, доцент, завідувач кафедри кримінальноправових дисциплін (Дніпровський гуманітарний університет)

ВЕРМЕНИЧ В. А., студет II курсу магістратури юридичного факультету (Дніпровський гуманітарний університет)

УДК 347.998.85

DOI https://doi.org/10.32842/2078-3736-2019-6-2-26

\title{
КОРУПЦІЯ ЯК АСОЦАЛЬНИЙ ФЕНОМЕН СУЧАСНОГО СУСПІЛЬСТВА УКРАЇНИ: КРИМІНАЛЬНО-ПРАВОВИЙ АСПЕКТ
}

У статті 3'ясовано сутність та особливості понять «корупція», «корупційні злочини», «корупційне правопорушення», «правопорушення, пов'язане 3 корупцією», а також відмінність корупційних злочинів від інших корупційних правопорушень. Проаналізовано динаміку змін щорічного індексу сприйняття корупції, визначену неурядовою організацією Transparency International (TI), згідно $з$ якою останнім часом в Україні прослідковується тенденція до зростання рівня корупції, що негативно позначається на міжнародному іміджі країни. Визначено такі основні проблемні питання корупції, як недотримання стратегії протидії корупції, неналежна організація виконання програмних антикорупційних заходів, відсутність політичної волі системно протидіяти корупції та слабкість контролю за антикорупційною діяльністю, у тому числі реалізацією відповідних програм і планів. Виокремлено основні ознаки корупційних злочинів, особливі властивості корупційних злочинів, які значно підвищують ïx суспільну небезпеку порівняно 3 іншими злочинними діяннями. Проаналізовано діяння, які відповідно до Кримінального кодексу України можуть бути віднесені до корупційних. 3'ясовано основні аспекти кримінальної відповідальності за корупційні правопорушення. Розглянуто наявність особливих властивостей корупційних злочинів, таких як надзвичайно висока латентність корупційних злочинів, інституціоналізація практик учинення корупційних злочинів, розвиненість технологій ухилення від політичної відповідальності та інші. Обгрунтовано доцільність покращення ефективності заходів щодо протидії та запобігання корупції, а також узагальнення та імплементації позитивного міжнародного досвіду у даному напрямі діяльності. Підкреслена необхідність розроблення концепції комплексного впливу на прояви корупції.

Ключові слова: корупиія, запобігання корупиії, протидія корупиї, корупчійні правопорушення, антикорупиійне законодавство, реформування законодавства.

The article deals with the essence and peculiarities of the concepts of corruption, corruption offenses, corruption offenses, corruption offenses, as well as the difference between corruption offenses and other corruption offenses. The dynamics of changes

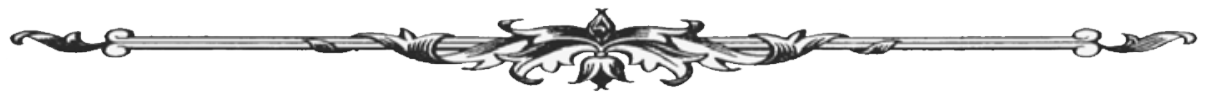


in the annual Corruption Perceptions Index, identified by the non-governmental organization Transparency International (TI), are analyzed, according to which the tendency to increase the level of corruption in Ukraine is being observed recently which negatively affects the country's international image. The main problematic issues of corruption are identified - non-compliance with the anti-corruption strategy, inadequate organization of anti-corruption program activities, lack of political will to systematically counteract corruption and weak control over anti-corruption activities, including implementation of relevant programs and plans. The main features of corruption crimes, the special properties of corruption crimes, which significantly increase their public danger in comparison with other criminal acts, are highlighted. The actions in accordance with the Criminal Code of Ukraine, which can be attributed to corruption, are analyzed. The basic aspects of criminal liability for corruption offenses have been clarified. Special features of corruption crimes are considered, such as extremely high latency of corruption crimes, institutionalization of practices of corruption crimes, development of technologies of evasion of political responsibility and others. The expediency of improving the effectiveness of measures to counteract and prevent corruption, as well as the generalization and implementation of positive international experience in this area of activity, is substantiated. The need to develop a concept of a comprehensive impact on the manifestations of corruption is emphasized.

Key words: corruption, prevention of corruption, counteraction to corruption, corruption offenses, anti-corruption legislation, reform of legislation.

Вступ. Корупційні злочини, з урахуванням їх суспільної небезпеки, вважаються одними із найбільш серйозних і небезпечних кримінальних правопорушень. 3 огляду на це науковці впродовж багатьох років намагаються знайти способи подолання цього негативного явища, але на даному етапі такі пошуки більшою мірою є безрезультатними, оскільки корупція як була невіддільним складником нашого повсякденного життя, так і нині залишається, навіть більше - продовжує вкорінятися. Корупція загрожує національній безпеці України, уповільнює економічний розвиток держави, що не сприяє надходженню іноземних інвестицій, а також нівелює довіру населення до державних органів та органів місцевого самоврядування. Крім того, масштаби корупційних проявів негативно позначаються на міжнародному іміджі України.

Враховуючи системність і поширеність цього явища, заходи, які вживаються для iіi запобігання та припинення, не виявили належної ефективності, що підтверджується динамікою змін щорічного індексу сприйняття корупції, визначеною неурядовою організацією Transparency International (TI), згідно з якою у період з 2012 по 2015 роки в Україні прослідковується тенденція до зростання рівня корупції: 2012 - 144 місце із 176, 2013 - 144, 2014 - 142, 2015 - 142. Дещо покращилося становище у 2016 - 131 місце, 2017 - 130 місце iз 180 країн (зменшення використання службового становища в органах виконавчої влади (показник покращився на 14\%), у поліції та збройних силах (показник покращився на 6\%)). У 2018 році Україна посіла 120 місце серед 180 країн (прослідковується зменшення рівня корупції у відносинах між бізнесом та державними структурами - запровадження автоматичного відшкодування податку на додану вартість, робота інституту бізнес-омбудсмена, функціонування електронних систем ProZorro) [1]. За висновками експертів, зниження оцінки індексу сприйняття корупції лише на один пункт призводить до відтоку з країни капіталу, що дорівнює $0,5 \%$ валового внутрішнього продукту держави. Для України ці цифри означають втрату щороку щонайменше 20 млрд гривень [2].

За останні роки в Україні у сфері протидії та запобігання корупції зроблено досить багато - створено спеціалізовані антикорупційні органи по боротьбі з корупцією (НАЗК, САП, НАБУ, НПУ, АРМА, ДБР), прийнято спеціальний антикорупційний закон та ряд інших законодавчих актів антикорупційного спрямування, схвалено Концепцію боротьби з корупцією

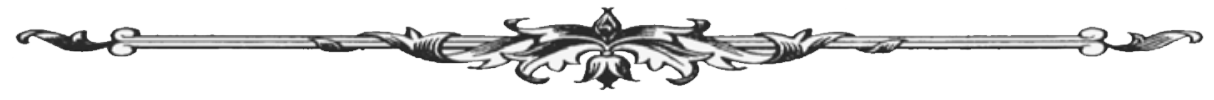


та спеціальну антикорупційну програму, запроваджено систематичне проведення організаційних заходів 3 питань протидії корупції тощо. Однак здійснювані заходи не дали відчутних позитивних результатів у вказаному напрямі. Це зумовлено низкою політичних, економічних, організаційно-управлінських, правових, ідеологічних, морально-психологічних факторів. До основних з них належать, зокрема, недотримання стратегії протидії корупції, неналежна організація виконання програмних антикорупційних заходів, відсутність політичної волі системно протидіяти корупції та слабкість контролю за антикорупційною діяльністю, у тому числі реалізацією відповідних програм і планів. Ефективна протидія корупції неможлива також без глибокого та послідовного наукового забезпечення, передусім без об'єктивного аналізу факторів корупції та реальної оцінки здійснюваних заходів.

Аналіз останніх досліджень і публікацій. Питанням щодо запобігання та протидії корупційним злочинам у нашій державі завжди приділяли й приділяють увагу не лише науковці (О.М. Бандурка, О.Ю. Бусол, В.М. Гаращук, Є.В. Додін, Д.Г. Заброда, О. Г. Кальман, М.І. Мельник, Є.В. Невмержицький, М.О. Потебенько, І.В. Пшеничний, С.С. Рогульський, О.П. Рябченко, І.В. Сервецький, О.В. Терещук, М.І. Хавронюк, Г.Л. Шведова, О.В. Шемякін, I.P. Шинкаренко, О.Н. Ярмиш та інші), але й правозастосовники, представники громадських організацій тощо. Проте, незважаючи на підвищену увагу та ступінь розробленості проблеми, вважати іiі вичерпаною аж ніяк не можна.

Постановка завдання. Метою статті є 3'ясування теоретичного аспекту щодо сутності та особливостей понять «корупція», «корупційний злочин», визначення видів відповідальності за корупційні правопорушення, а також кримінально-правових наслідків за їх вчинення з точки зору вітчизняного законодавства.

Результати дослідження. Слід зазначити, що єдиної позиції щодо визначення поняття «корупція» немає. Так, у етимологічному розумінні “corruptio” (у перекладі $з$ лат. розбешееня, порча, підкуn) - це підкуп державних, політичних, громадських діячів, посадових осіб державного апарату, вчинений особою в певних вузько корпоративних (кланових) інтересах [3]. На думку Л.В. Багрія-Шахматова, корупція - це явище, яке вразило апарат державної влади й управління, пов'язане з його розладом, коли представники апарату незаконно використовують своє службове становище в корисливих цілях, для особистого збагачення всупереч інтересам служби [4]. Л.І. Аркуша визначає корупцію як протиправну діяльність певних осіб, спрямовану на використання свого службового та суспільного статусу для особистого збагачення, збагачення своїх родичів і прибічників, отримання інших переваг і благ усупереч інтересам суспільства [5]. Прагнучи надати узагальнену дефініцію корупції, ООН у своєму Довідковому документі по боротьбі з корупцією, визначає це явище «як зловживання державною владою для задоволення особистих інтересів» [6].

Зважаючи на те, що сьогодні у правовій науці відбувається перехід від сприйняття корупції як явища суто юридичного, на нашу думку, необхідно формулювати поняття корупції як складного соціального явища. Так, С.С. Рогульський вважає, що корупція не завжди проявляється однаково й не завжди має однакові наслідки та мотивацію. Однак де і коли б вона не проявлялася, корупція завжди завдає шкоди нормальному функціонуванню суспільства, оскільки важливі рішення приймаються на підставі прихованих мотивів без урахування інтересів громадськості [7].

Нам імпонує думка M.I. Мельника про те, що закріплення дефініції корупції є характерним для країн, які перебувають на перехідному етапі свого розвитку та характеризуються високим рівнем корумпованості державного апарату, й зумовлюється насамперед політичними вимогами та сподіваннями таким чином підвищити ефективність боротьби з цим явищем. Країни ж з розвинутою ринковою економікою та демократичним суспільством підходять до розв'язання цієї проблеми більш стримано й виважено, уникаючи визначення поняття «корупція» на законодавчому рівні.

Незважаючи на плюралізм підходів до формулювання дефініції корупції, важливе значення для організації діяльності державних органів у галузі боротьби 3 цим явищем має іiї закріплення як правової категорії. Таке визначення міститься у Законі України «Про

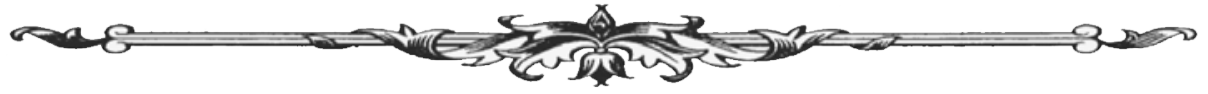


запобігання корупції»: «корупція - використання особою наданих їй службових повноважень чи пов'язаних з ними можливостей з метою одержання неправомірної вигоди або прийняття такої вигоди чи прийняття обіцянки / пропозиції такої вигоди для себе чи інших осіб або, відповідно, обіцянка / пропозиція чи надання неправомірної вигоди особі, зазначеній у частині першій статті 3 цього Закону, або на ії вимогу іншим фізичним чи юридичним особам 3 метою схилити цю особу до протиправного використання наданих ій службових повноважень чи пов'язаних з ними можливостей» [8].

Варто акцентувати увагу на тому, що Закон оперує двома схожими термінологічно поняттями: «корупційне правопорушення» та «правопорушення, пов’язане 3 корупцією». При цьому визначає, що корупційним правопорушенням слід розуміти діяння, що містить ознаки корупції, вчинене вказаною в законі особою, за яке законом встановлено кримінальну, дисциплінарну та/або цивільно-правову відповідальність. Під корупційними правопорушеннями, за які передбачена кримінальна відповідальність, розуміються корупційні злочини.

Проте наразі у вітчизняному кримінальному законодавстві відсутній системний підхід до розуміння корупційних злочинів та відповідальності за них: кримінальний закон не містить визначення поняття корупційного злочину і розкриває його зміст шляхом перерахування у примітці до ст. 45 Кримінального кодексу України (далі - ККУ) усіх діянь, що можуть бути віднесені до корупційних: ст. 210 (нецільове використання бюджетних коштів, здійснення видатків бюджету чи надання кредитів 3 бюджету без встановлених бюджетних призначень або з їх перевищенням); ст. 354 (підкуп працівника підприємства, установи чи організації); ст. 364 (зловживання владою або службовим становищем); ст. 364-1 (зловживання повноваженнями службовою особою юридичної особи приватного права незалежно від організаційно-правової форми); ст. 365-2 (зловживання повноваженнями особами, які надають публічні послуги); ст. 368 (прийняття пропозиції, обіцянки або одержання неправомірної вигоди службовою особою); ст. 368-2 (незаконне збагачення); ст. 368-3 (підкуп службової особи юридичної особи приватного права незалежно від організаційно-правової форми); ст. 368-4 (підкуп особи, яка надає публічні послуги); ст. 369 (пропозиція, обіцянка або надання неправомірної вигоди службовій особі); ст. 369-2 (зловживання впливом). Також корупційними злочинами, відповідно до цього Кодексу, вважаються злочини, передбачені статтями $191,262,308,312,313,320,357,410$, у випадку їх вчинення шляхом зловживання службовим становищем. Слід зазначити, що це перше використання терміну «корупційний злочин» на законодавчому рівні.

Більшість корупційних злочинів передбачають у санкціях статей як додаткове покарання позбавлення права обіймати певні посади або займатися певною діяльністю. У разі відсутності такого виду покарання в санкції статті, воно може бути призначено судом за умови, що з урахуванням характеру злочину, вчиненого за посадою або у зв'язку із заняттям певною діяльністю, особи засудженого та інших обставин справи суд визнає за неможливе збереження за ним права обіймати певні посади або займатися певною діяльністю (ч. 2 ст. 55 ККУ). Деякі санкції статей за корупційні злочини передбачають можливість призначення одразу двох додаткових покарань - позбавлення права обіймати певні посади або займатися певною діяльністю та конфіскацію або штраф (ст. 364 та ст. 368-2 ККУ).

Говорячи про відмінність корупційних злочинів від інших корупційних правопорушень, слід повністю погодитися з В.М. Киричко, який критерій такого відмежування вбачає у ступені суспільної небезпечності діяння [9]. На думку В.І. Тютюгіна та К.С. Косінової, аналіз складів злочинів, зазначених у примітці до ст.45 Кримінального кодексу України, свідчить, що їх складають діяння, які істотно різняться як за своїм складом, так і за ознаками [10]. Правознавці виокремлюють основні ознаки, які є спільними для цих діянь: у ст.45 Кримінального кодексу України всі корупційні злочини розподілені на дві відносно самостійні групи: а) безумовно корупційні, що передбачені статтями 210, 354, 364, 364-1, 365-2, 368 369-2 (вказана група злочинів зазвичай пов'язана зі зловживанням владою чи службовим становищем, а також можливостями, які випливають із такого становища особи або ж пов'язані з одержанням неправомірної вигоди від іншої особи (можливість одержання якої так

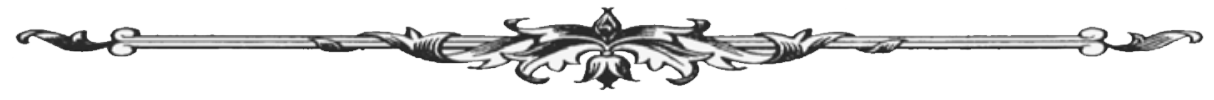


само пов’язана з обійманням особою певної посади)); б) такі, що вважаються корупційними лише за умови їх вчинення шляхом зловживання службовим становищем - статті 191, 262, $308,312,313,320,357,410$ (діяння як ознака об’ єктивної сторони в них передбачається альтернативно (викрадення, привласнення, вимагання, заволодіння в ст. 262 Кримінального кодексу України тощо), і тому законодавець прямо вказує, що не будь-яка форма об'єктивної сторони вказаних злочинів дозволяє віднести їх до корупційних, а лише така, яка має своїм способом використання службового становища винного) [11].

З урахуванням вищевикладеного ми дійшли висновку, що основними ознаками корупційних злочинів $є$ : а) їх вчинення завжди пов'язано з використанням особою влади, службового становища чи можливостей, які з такого службового становища випливають (наприклад, у ст. 369-2 ККУ); б) для корупційних злочинів характерним є не лише використання службового становища, а зловживання таким становищем. Тобто корупційним може визнаватися лише такий злочин, в якому вчинене діяння суперечить інтересам службової діяльності особи; в) злочинам, передбаченим приміткою до ст. 45 Кримінального кодексу України, властиве винятково умисне психічне ставлення до вчинюваного діяння (особа завжди усвідомлює, що використовує службові повноваження чи пов'язані з ними можливості всупереч інтересам служби і бажає їх використати саме так). При цьому в злочинах, передбачених статтями 364, 364-1, 365-2 Кримінального кодексу України, ставлення до наслідків може виражатися як у формі умислу, так й у формі необережності. Варто також вказати, що, незважаючи на те, що мотиви та мета можуть бути різними, у більшості корупційних злочинів (статті 191, 354, 357, 364, 364-1, 365-2, 368, 368-2, 368-3, 368-4, ч. 2 та 3 ст. 369-2 ККУ) обов'язковою $є$ наявність корисливого мотиву; г) корупційні злочини здебільшого пов'язані з одержанням чи даванням (у тому числі пропозицією і обіцянкою таких дій) неправомірної вигоди. У той самий час у злочинах, передбачених статтями 354, 368, 368-2, 368-3, 368-4, 369, 369-2 ККУ, неправомірна вигода є предметом цих злочинів, тоді як у ст. 364, 364-1, 365-2 ККУ неправомірна вигода характеризує суб' єктивну сторону цих злочинів, виступаючи в якості мети їх вчинення; д) характерною ознакою корупційних злочинів є суб’єкт їх вчинення: у більшості це службові особи як публічного, так і приватного права, та особи, які надають публічні послуги (виняток становлять лише злочини, передбачені ст. 354 ККУ, суб'єктом яких є працівник державного підприємства, установи чи організації, незалежно від роду діяльності, який не є службовою особою, а також ч. 1 та 2 ст.ст. 368-3 та 368-4, ст. 369, та ч. 1 ст. 369-2 ККУ, де суб'єкт злочину є загальним; е) формулюючи поняття корупційних злочинів, законодавець використав не традиційний спосіб визначення понять через рід і видову відмінність, вказуючи на ті ознаки, які мають бути притаманні всім діянням, що становлять вказану категорію, а спосіб перелічення всіх предметів і явищ, до яких застосовне це поняття [11].

Сутність поширеної в Україні корупції підтверджує також і наявність особливих властивостей корупційних злочинів, які значно підвищують їх суспільну небезпеку порівняно $з$ іншими злочинними діяннями й такими самими злочинами, які вчиняються у країнах із незначним поширенням корупції: a) спричинення корупційними злочинами прямих суспільно небезпечних наслідків у вигляді порушення охоронюваних нормами Кримінального кодексу про ці злочини суспільних відносин, а також обов'язкових похідних суспільно небезпечних наслідків широкому спектру інших суспільних відносин; б) надзвичайно висока латентність корупційних злочинів; в) інституціоналізація практик учинення корупційних злочинів; г) здійснення корупційних злочинів у межах корупційних мереж, приховування окремих діянь і захист такими мережами суб' єктів зазначених злочинів; д) виконання корупцією функції підтримання керованості апарату публічного управління, що необхідно суб'єктам, які зобов'язані протидіяти корупції, але підтримують їі; е) розвиненість технологій ухилення від політичної відповідальності, у тому числі за вчинену чи допущену, але не покарану корупцію, а також за нездійснення реальної протидії їй, що суттєво знижує мотивацію до антикорупційної діяльності та гальмує процеси формування політичної волі для цього [12].

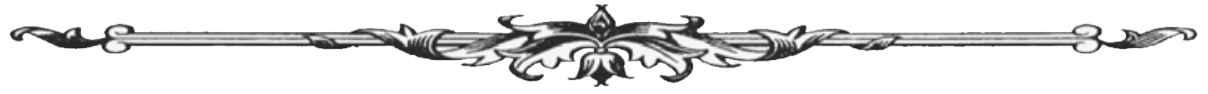


Корупція - проблема не лише українська, але й міжнародна. Над її розв'язанням працюють такі міжнародні організації, як ООН, Європейський парламент, Організація безпеки та співтовариства в Європі тощо. Позитивним є той факт, що світова спільнота для активної протидії корупції постійно узагальнює передовий досвід у цій сфері та виробляє конкретні та дієві рекомендації.

Висновки. Підсумовуючи, зазначимо, що для забезпечення ефективної державної політики протидії корупційній злочинності має бути розроблена концепція комплексного впливу на прояви корупції, яка, серед іншого, включає: підвищення рівня правової культури та правосвідомості громадян, соціальні заходи, наукове супроводження реалізації державних заходів протидії; побудову дієвої системи кримінальної юстиції; встановлення практичного міжнародного співробітництва, яке сприятиме гармонізації вітчизняної правової системи з положеннями відповідного законодавства міжнародної спільноти; запровадження багатоступеневої методики оцінки корупційних ризиків у законодавстві як на рівні розробників проектів нормативно-правових актів (формалізована самооцінка), на рівні спеціалізованих підрозділів (базова офіційна експертиза перед прийняттям відповідного акта), на рівні громадської (неофіційної) експертизи, яка забезпечується існуванням прозорої процедури нормопроєктування та доступністю інформації для громадськості, так і на рівні контрольної експертизи, з подальшим узагальненням практики проведення такої експертизи, 3 метою виявлення та усунення виявлених системних недоліків під час розроблення проектів актів.

Список використаних джерел:

1. Індекс корупції CPI-2018. Transparency International Ukraine. URL: http://ti-ukraine. org/CPI-2018.

2. Маркєєва О. Актуальні проблеми антикорупційної політики України: аналітична записка. Національний інститут стратегічних досліджень. URL: http://www.niss.gov.ua/ articles/395.

3. Етимологічний словник української мови: в 7 т. Київ : Наукова думка, 1982. 632 с.

4. Багрий-Шахматов Л.В. Уголовно-правовые и криминологические проблемы коррупции, теневой экономики и борьбы с ними. Одесса : Ластар, 2001. 530 с.

5. Аркуша Л.И. Выявление и расследование организованной преступной деятельности при наличии коррупционных связей. Одесса : Одесская нац. юр. академия, 2003. 207 с.

6. Довідковий документ про міжнародну боротьбу з корупцією, підготовлений Секретаріатом ООН. Каїр, 1995. С. 69.

7. Рогульський С.С. Адміністративно-правові заходи боротьби з корупцією в Україні : дис. ... канд. юрид. наук : 12.00.07. Київський національний університет імені Т. Шевченка. Київ, 2005. 187 с.

8. Про запобігання корупції: Закон України від 14.10.2014 № 1700-VII. Biдомості Верховної Ради (ВВР). 2014. № 49. Ст. 2056.

C. 14 .

9. Киричко В.М. Кримінальна відповідальність за корупцію. Харків : Право, 2013.

10. Тютюгін В.I. Поняття та ознаки корупційних злочинів. Вісник Асоичіаџї̈ кримінального права України. 2015. № 1 (4). С. 363-366.

11. Кримінальний кодекс України: Закон України від 05 квітня 2001 р. № 2341-III. Відомості Верховної Ради України. 2001. № 25-26. Ст. 131 (із змінами).

12. Михайленко Д.Г. Концепція кримінально-правової протидії корупційним злочинам в Україні : дис. ... докт. юрид. наук : 12.00.08. Одеса, 2018. 505 с.

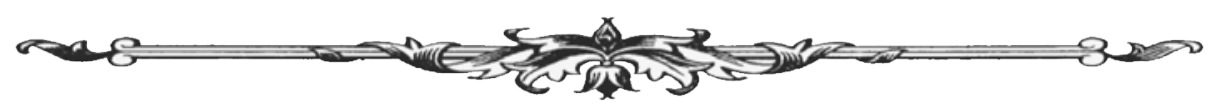

